\title{
Ruminta
}

\section{Analisis penurunan produksi tanaman padi akibat perubahan iklim di Kabupaten Bandung Jawa Barat}

\section{Analysis of decreasing production of paddy due to climate change in Bandung district West Java}

Diterima : 15 Februari 2016/Disetujui : 1 Maret 2016 / Dipublikasikan : Maret 2016

CDepartment of Crop Science, Padjadjaran University

\begin{abstract}
Climate change has a significant impact on paddy cultivation, because paddy cultivation has a heavy reliance on climate elements, especially rainfall and temperature. Associated with it has been studied the impact of climate change on the decreating production of paddy in the area of Bandung District, West Java. The research object was to determine the impacts of climate change on the decreating production of paddy and identify adaptation efforts should be done by farmers. The results of study showed that the impact of climate change in Bandung Diatrict has been felt by farmers that's indicated by the shift of the growing season and harvest time, a decrease in planting and harvested area, changes in productivity and production of paddy in the rainfed and semi-irrigated lands. There are some sub-districts that experienced a hazard on decrease in the production of paddy are the Cicalengka, Pangalengan, Ciwidey, Solokanjeruk, and Ciparay. The regions experienced a vulnerability to climate change are Pasirjambu, Cimaung, Pangalengan, Kertasari, and Pacet Sub-Districts (very high level of vulnerability). There are region that are at risk of decrease in the production of paddy are Pasirjambu, Cimaung, and Ciparay Sub-Districts. There are several strategic adaptation efforts to deal with the risk of a decline in production of paddy due to climate change are the use of highyielding paddy varieties that's resistant to drought/floods and early harvested; improving techniques and intensification of paddy cultivation for example PTT, SRI, and the Legowo System; and optimalization the utilization of idle land and create new wetland.
\end{abstract}

Keywords : Paddy · Climate change $\cdot$ Strategic adaptation

\footnotetext{
Dikomunikasikan oleh Tati Nurmala

Ruminta

Departemen Budidaya Pertanian Universitas Padjadjaran

Korespondensi: r_ruminta@yahoo.com
}

Sari. Perubahan iklim mempunyai pengaruh signifikan pada budidaya tanaman padi, karena budidaya tanaman padi mempunyai ketergantungan yang kuat terhadap unsur iklim terutama curah hujan dan temperatur. Terkait dengan hal itu telah dilakukan kajian dampak perubahan iklim terhadap penurunan produksi tanaman padi di wilayah kabupaten Bandung Jawa Barat. Penelitian bertujuan untuk mengetahui dampak perubahan unsur iklim (curah hujan dan temperature) terhadap produksi tanaman padi dan mengidentifikasi usaha adaptasi yang harus dilakukan oleh para petani. Hasil penelitian menunjukkan bahwa dampak perubahan iklim di wilayah kabupaten Bandung sudah dirasakan oleh petani yang diindikasikan oleh bergesernya musim tanam dan waktu panen, penurunan luas tanam dan panen, perubahan produktivitas dan produksi padi di lahan sawah tadah hujan dan lahan sawah $1 / 2$ irigasi. Ada beberapa kecamatan yang mengalami bahaya (hazard) penurunan produksi tanaman padi adalah kecamatan Cicalengka, Pangalengan, Ciwidey, Solokanjeruk, dan Ciparay. Wilayah mengalami kerentanan (vulnerability) akibat perubahan iklim adalah kecamatan Pasirjambu, Cimaung, Pangalengan, Kertasari, dan Pacet (tingkat kerentanan sangat tinggi). Wilayah yang mempunyai risiko penurunan produksi tanaman padi adalah kecamatan Pasirjambu, Cimaung, dan Ciparay. Ada beberapa usaha adaptasi strategis untuk menghadapi risiko penurunan produksi tanaman padi akibat perubahan iklim adalah penggunaan varitas padi unggul yang tahan kekeringan/ banjir serta berumur genjah; meningkatkan teknik dan intensifikasi budidaya tanaman padi misalnya PTT, SRI, dan sistem Legowo; dan optimalisasi pemanfaatan lahan tidur dan pembukaan lahan sawah baru.

Kata kunci : Padi · Perubahan iklim · Adaptasi strategis 


\section{Pendahuluan}

Perubahan iklim mengancam sistem produksi tanaman dan oleh karena itu juga mengancam mata pencaharian dan ketahanan pangan untuk miliaran orang yang bergantung pada pertanian. Bukti menunjukkan bahwa populasi penduduk yang terpinggirkan akan menderita luar biasa akibat dampak perubahan iklim dibandingkan dengan populasi kaya, seperti negara-negara industri (IPCC 2007). Tidak hanya negaranegara relatif miskin akan mengalami dampak lebih parah, tetapi juga mereka yang sering kekurangan sumber daya untuk menyiapkan dan mengatasi risiko perubahan lingkungan. Pertanian adalah sektor yang paling rentan terhadap perubahan iklim karena ketergantungan tinggi pada iklim dan cuaca dan juga karena orang yang terlibat di sektor pertanian cenderung lebih miskin dibandingkan dengan rekan-rekan mereka di kota.

Pengaruh perubahan iklim khususnya terhadap sektor pertanian di Indonesia sudah terasa dan menjadi kenyataan. Perubahan ini diindikasikan antara lain oleh adanya bencana banjir, kekeringan (musim kemarau yang panjang) dan bergesernya musim hujan. Dalam beberapa tahun terakhir ini pergeseran musim hujan menyebabkan bergesernya musim tanam dan panen komoditi pangan (padi, palawija dan sayuran). Sedangkan banjir dan kekeringan menyebabkan gagal tanam, gagal panen, dan bahkan menyebabkan puso.

Di Indonesia, perubahan pola hujan mungkin adalah ancaman terbesar, karena begitu banyak petani mengandalkan langsung pada hujan untuk kegiatan pertanian dan mata pencahariannya, setiap perubahan curah hujan menyebabkan resiko besar. Pertanian tadah hujan sangat rentan terhadap perubahan iklim, jika praktek bertani tetap tidak berubah. Suhu yang lebih tinggi akan menantang sistem pertanian. Tanaman sangat sensitif terhadap suhu tinggi selama tahap kritis seperti berbunga dan perkembangan benih. Seringkali dikombinasikan dengan kekeringan, suhu tinggi dapat menyebabkan bencana untuk lahan pertanian. Perubahan suhu dan kelembaban udara juga dapat memicu perkembangan dan ledakan hama dan penyakit tanaman. Banjir dan kekeringan juga mempengaruhi produksi pertanian. Banjir dan kekeringan yang berkepanjangan akibat dari pengelolaan air yang tidak baik dan kapasitas yang rendah mengakibatkan penurunan produksi yang signifikan.
Berdasarkan pada fakta tersebut, para ahli iklim berpendapat bahwa variasi iklim yang tidak beraturan itu sangat berkaitan dengan kejadian iklim ekstrim yakni ENSO (El Nino Southern Oscillation). Misalnya, Boer dan Meinke (2002) mengemukakan bahwa di daerah monsoon seperti Jawa, Indonesia Timur dan Sumatera bagian Selatan, bahwa pada musim-musim tertentu Osilasi Selatan berpengaruh kuat terhadap faktorfaktor iklim seperti hujan, perubahan penutupan awan yang mempengaruhi radiasi, suhu, penguapan dan kelembaban udara yang semuanya akan mempengaruhi pertumbuhan tanaman. Kejadian iklim ekstrim seperti El Nino dan La Nina di Indonesia berpengaruh terhadap perkembangan produksi tanaman pangan. Kuatnya pengaruh ENSO itu dapat dibuktikan dengan melihat kejadian kemarau panjang dan kekeringan di berbagai wilayah di Indonesia yang bertepatan dengan kejadian El Nino (Yasin et al., 2002).

Hubungan antara fenomena El Nino dengan produksi tiga tanaman pangan utama di Indonesia ditunjukkan pada Gambar 1. Fenomena El Nino pada kurun waktu 20 tahun terakhir terjadi pada tahun 1994, 1997, 2001, 2003, 2004, dan 2006. Pada tahun El Nino tersebut berdampak kuat terhadap produktivitas dan produksi tanaman padi dan jagung di Indonesia. Gambar 1 terlihat dengan jelas bahwa produktivitas dan produksi tanaman padi dan jagung mengalami penurunan yang sangat signifikan.
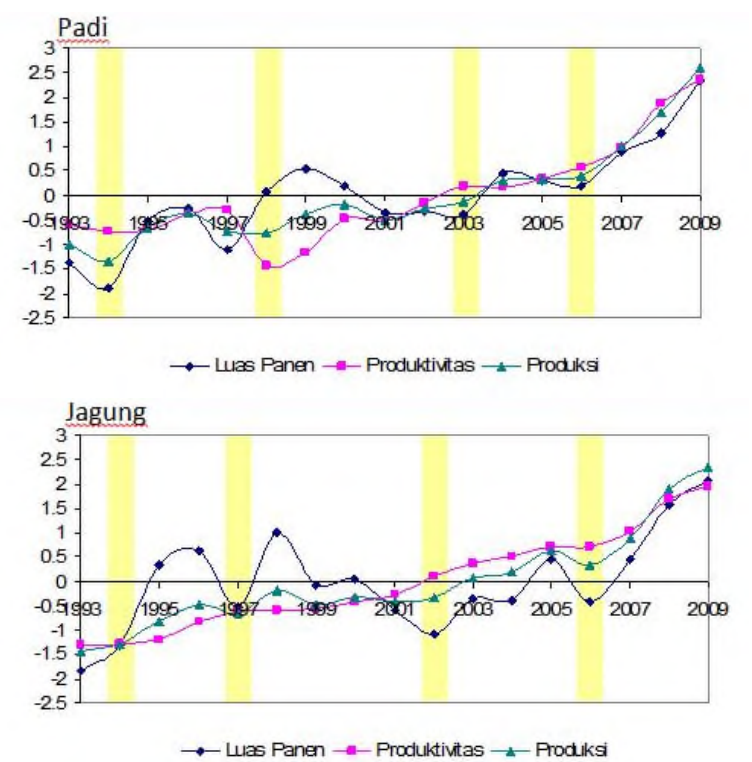

Gambar 0. Luas panen dan produksi tanaman pangan utama (Padi dan Jagung) di Indonesia (1993-2009) (Garis kuning menunjukkan tahun kejadian El Nino) (Ruminta dan Handoko. 2012a). 
Tingkat dimana peristiwa perubahan iklim mempengaruhi sistem pertanian tergantung pada berbagai faktor, antara lain jenis tanaman yang diusahakan, skala operasi, orientasi pertanian terhadap tujuan komersial atau subsistensi, kualitas basis sumber daya alam, dan variabel manusia atau manajer pertanian (misalnya pendidikan, usia, toleransi resiko dll). Adanya keragaman pola iklim, sistem pertanian, kondisi sosial, ekonomi, politik dan lingkungan maka bahaya, kerentanan, dan risiko perubahan iklim akan berbeda dari satu tempat ke tempat lainnya, hal ini tentu menjadi tantangan untuk mengkaji bahaya, kerentanan, dan risiko di suatu wilayah termasuk kabupaten Bandung. Perlu dilakukan identifikasi terhadap bidang pertanian, sistem produksi, dan populasi yang paling bahaya, rentan, dan berisiko terhadap perubahan iklim. Kajian tersebut pada tingkat lokal lebih difokuskan pada upaya mengamankan tujuan pembangunan lokal melalui kajian bahaya, kerentanan, dan risiko perubahan iklim dalam upaya mendukung peningkatan ketahanan pangan. Perlu dilakukan kajian kerentanan secara lokal seperti di kabupaten Bandung untuk melihat tingkat bahaya, kerentanan, dan risiko untuk menentukan kebijakan dan strategi adaptasi berdasarkan kebutuhan dan kondisi daerah tersebut. Tujuan penelitian adalah mengkaji bahaya, kerentanan, risiko, dan adaptasi perubahan iklim pada sektor pertanian di kabupaten Bandung. Tujuan lainnya adalah membentuk basis pengetahuan tentang dampak perubahan iklim dan membangun kapasitas adaptif dan ketahanan jangka panjang di kabupaten Bandung terhadap variabilitas dan perubahan iklim. Kajian ini juga menawarkan pilihan adaptasi strategis untuk mengatasi ancaman perubahan iklim pada sistem pertanian tanaman padi. Hasil analisis diharapkan akan dapat menjadi bahan pertimbangan dalam penyusunan pedoman untuk melakukan adaptasi secara lokal.

Kabupaten Bandung terletak di sebelah Selatan garis khatulistiwa pada 107022' Bujur Timur sampai 108 o50’ Bujur Timur dan antara 6041' Lintang Selatan dan 7019' Lintang Selatan. kabupaten Bandung meliputi areal seluas $1.665,83 \mathrm{~km}^{2}$ (166.583 Ha) atau 4,7\% dari luas Jawa Barat $\left(37.173,97 \mathrm{~km}^{2}\right)$. kabupaten Bandung dialiri oleh beberapa sungai. Sungai yang terbesar adalah Sungai Citarum. Keberadaan sungai ini menguntungkan untuk sektor pertanian, industri, dan bahan baku air, namun bila curah hujan cukup tinggi dari daerah- daerah tertentu akan terjadi genangan air. Topografi kabupaten Bandung adalah datar, berombak, sampai berbukit, lahan sawah sebagian besar terletak pada dataran medium dengan ketinggian 500 - $750 \mathrm{~m}$ dpl, seperti tersebar di kecamatan Paseh, Cikancung, Cicalengka, Rancaekek, Majalaya, Solokan Jeruk, Ciparay, Baleendah, Cangkuang, Banjaran, Pameungpeuk, Katapang, Soreang, Margaasih, Margahayu, Dayeuhkolot, dan Bojongsoang. Sumber air yang utama di kabupaten Bandung adalah berupa sungai, mata air, danau, embung dan bendungan (dam). Wilayah kabupaten Bandung beriklim tropis dan basah. Sepanjang tahun kabupaten ini hanya dipengaruhi oleh dua musim, yakni musim hujan dan musim kemarau. Suhu udaranya bervariasi antara 24,7 sampai 32,9 ${ }^{\circ} \mathrm{C}$ dengan tingkat kelembaban udara berkisar antara 82 sampai $88 \%$. Musim hujan antara bulan Oktober sampai bulan April. Variasi curah hujan berkisar antara $2.100 \mathrm{~mm}$ sampai $3.264 \mathrm{~mm}$. Biasanya bulan Desember merupakan bulan dengan curah hujan paling tinggi. Musim kemarau biasanya antara bulan Juni sampai bulan September. Tipe iklim di wilayah kabupaten Bandung adalah D2, C2, dan B1 dengan 6-8 bulan basah dan 1-3 bulan kering per tahun (Oldeman, 1975).

Berdasarkan tataguna lahan di kabupaten Bandung, luas lahan untuk kegiatan pertanian tanaman pangan meliputi $54.261,67$ ha atau $24.38 \%$ dari luas total wilayah kabupaten Bandung. Lahan pertanian tersebut terdiri dari lahan basah (sawah) seluas 37.033,59 ha dan lahan kering (ladang) seluas $12.577,74$ ha. Tipe lahan sawah di kabupaten Bandung terdiri dari sawah irigasi teknis, sawah irigasi non teknis, dan sawah tidak berpengairan. Namun demikian, sawah irigasi non teknis merupakan tipe lahan sawah yang paling dominan diusahan oleh petani di kabupaten Bandung. Produktivitas lahan sawah tadah hujan di kabupaten Bandung berkorelasi dengan pola curah hujan karena sumber airnya bergantung sepenuhnya pada air hujan. Rata-rata curah hujan tahunan bervariasi menurut musim dan wilayah. Sekitar $80 \%$ curah hujan tahunan terjadi antara bulan September dan Februari. Periode April Agustus benar-benar kering dan menghasilkan kurang dari 10\% curah hujan tahunan (Abawi et al., 2002).

Implikasi dari awal musim hujan dan musim kemarau di kabupaten Bandung sangat menentukan saat memulai musim tanam dan musim panen. Lahan irigasi dan tadah hujan di 
Tabel 1. Alternatif Pola Tanam Tahunan di Kabupaten Bandung.

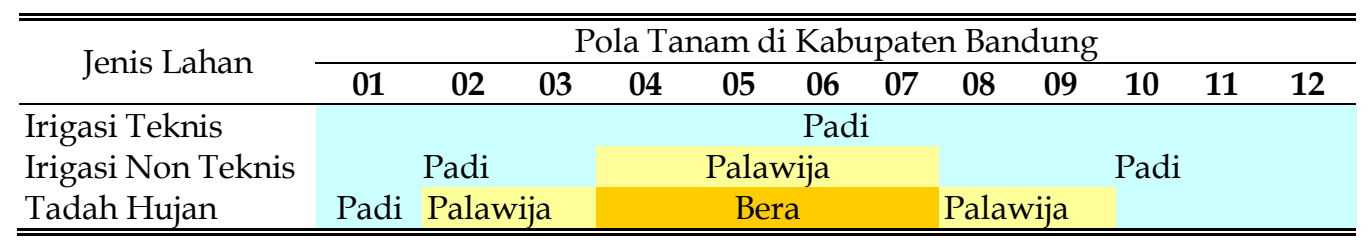

kabupaten Bandung ada dua musim tanam dalam setahun, yakni (1) Musim Tanam I disebut Musim Hujan (MH) dari bulan September sampai dengan Februari, pada musim ini pada umumnya petani menanam padi; (2) Musim Tanam II disebut Musim Kering 1 (MK) dari bulan April sampai dengan Agustus, pada musim ini umumnya petani menanam padi pada daerah yang sawahnya beririgasi teknis dan palawija pada daerah yang non irigasi. Secara rinci pola tanam di kabupaten Bandung dapat dituangkan dalam Tabel 1.

Padi di sawah irigasi non teknis dapat ditanam dua kali dalam setahun, sedangkan padi di sawah tadah hujan hanya dapat ditanam dalam satu kali dalam setahun. Padi pada lahan tadah hujan seluas 7.016,75 ha, dapat dikembangkan menjadi sawah irigasi dengan dukungan kegiatan rehabilitasi sarana irigasi/drainase, tata air mikro, pengembangan alsintan (traktor tangan dan pompa air), penggunaan benih unggul (varietas genjah), pemupukan, penyuluhan dan pendampingan (Pemerintah kabupaten Bandung, 2010). Pola tanam yang berkembang di masyarakat tani kabupaten Bandung saat ini mengacu pada pola tanam yang berlaku secara nasional dengan pola mengikuti sebaran curah hujan. Sebagian besar wilayah lahan sawah irigasi telah dilakukan pertanaman dengan indeks pertanaman (IP) 200, yaitu di awal musim hujan satu kali (Januari April) dan akhir musim hujan satu kali (Mei Agustus). Sistem pertanaman dilakukan secara serentak, baik saat tanam maupun panen. Hal ini dilakukan agar memudahkan dalam pengaturan tata air, pendampingan oleh petugas lapangan dan memudahkan dalam mengendalikan hamapenyakit yang mungkin timbul. Pada bulan September, dilakukan penanaman palawija (seperti jagung) dan setelah itu diberakan untuk persiapan penanaman padi selanjutnya.

Di kabupaten Bandung, padi ditanam pada lahan basah dan ladang. Lahan basah meliputi padi sawah tadah hujan dan padi sawah irigasi. Hampir seluruh kecamatan di kabupaten Bandung memproduksi padi sawah maupun ladang. Kecamatan Ciparay menjadi produsen terbesar padi dengan luas panen seluas 5.757 hektar. Pada tahun 2008, kabupaten Bandung mempunyai luas panen 718.797 ha dengan produksi 2.971.286 ton. Rata-rata produksi padi sawah sawah adalah 6,24 ton per hektar, sementara padi ladang hanya mencapai 3,25 ton per hektar pada tahun 2009 (BPS kabupaten Bandung, 2013).

\section{Bahan dan Metode}

Data yang digunakan dalam analisis ini merupakan data skunder yang diperoleh dari BMKG, LAPAN, BPS, dan Dinas Pertanian Kabupaten Bandung dari tahun 1993 hingga 2013 Data tersebut adalah data curah hujan dan suhu udara, pola tanam, sumber daya air (irigasi), tata guna lahan pertanian, ketinggian tempat, dan data sosial ekonomi. Data lainnya adalah produksi dan produktivitas tanaman padi, gagal tanam, gagal panen, banjir, kekeringan, ledakan hama penyakit tanaman, konversi lahan sawah, dan luas lahan sawah yang rentan terhadap ancaman bahaya perubahan iklim.

Penelitian ini menggunakan metode deskriptif eksplanatif. Analisis dan interpretasi data penelitian menggunakan GIS dan Surfer 8.0. Kajian potensi bahaya, kerentanan, risiko, dan adaptasi perubahan iklim pada sektor pertanian di kabupaten Bandung merupakan penelitian skala meso (Meso Level Study). Kajian difokuskan pada analisis dampak perubahan iklim dan variabilitas iklim seperti temperatur dan pola perubahan curah hujan bulanan, serta peningkatan frekuensi dan intensitas kejadian ekstrim (extreme event) seperti Nina dan El Nino. Ada tiga aspek dampak dari perubahan iklim yang dianalisis, yaitu analisis kejadian bahaya (hazard), kerentanan (vulnerability) dan tingkat risiko (risk). Kerentanan adalah tingkat kemampuan suatu individu atau kelompok masyarakat, komunitas dalam mengantisipasi, menanggulangi, mempertahankan kelangsungan hidup dan menyelamatkan diri dari dampak yang ditimbulkan oleh bahaya secara alamiah. Kerentanan tersebut selalu berubah seiring dengan perubahan kondisi sosial ekonomi dan 
kondisi lingkungan hidup di sekitarnya. Alur kajian bahaya, kerentanan, risiko, dan adaptasi perubahan iklim pada sektor pertanian di kabupaten Bandung disajikan pada Gambar 2.

Menilai dan menganalisis dampak perubahan iklim pada sektor pertanian sangat didukung oleh hasil kajian lain yaitu (1) kajian tentang perubahan iklim itu sendiri dan (2) kajian tata air (water balance) sebagai dampak perubahan iklim.

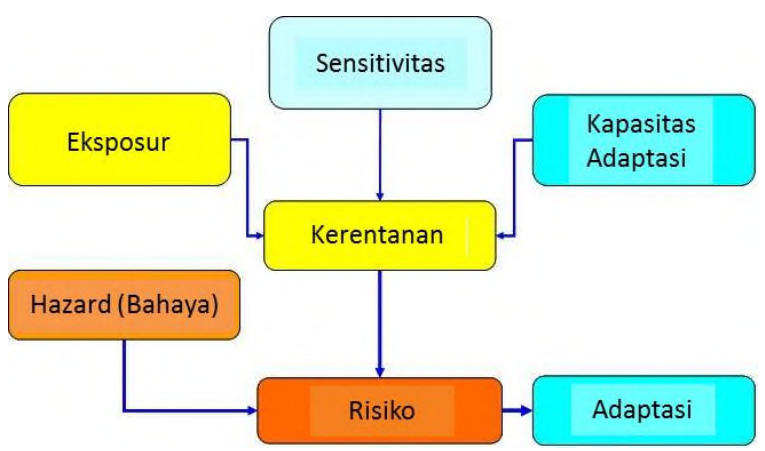

\section{Gambar 2. Diagram Alir Framework Kajian \\ Bahaya (Hazard), Kerentanan (Vulnerability), Risiko (Risk), dan Adaptasi (Adaptation) \\ Perubahan Iklim pada Sektor Pertanian (Ruminta dan Handoko, 2012a).}

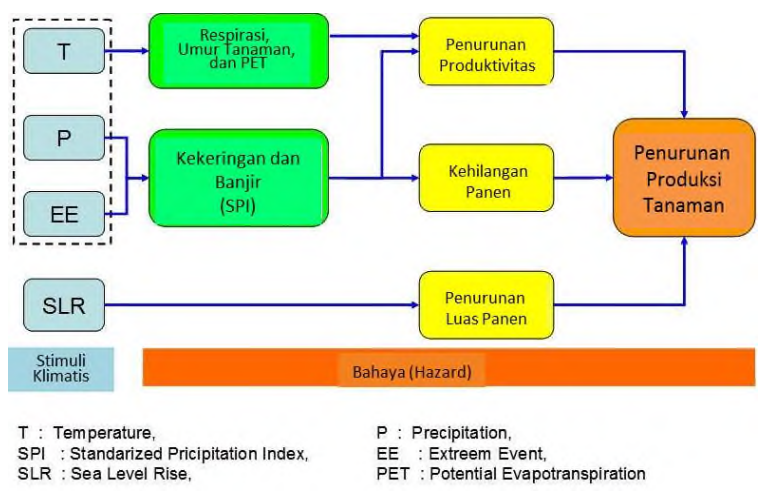

Gambar 3. Diagram alir analisis stimuli klimatis dan potensi hazard perubahan iklim pada sektor pertanian (Ruminta dan Handoko, 2012b).

Kajian bahaya, kerentanan, risiko dan adaptasi perubahan iklim pada sistem pertanian padi sawah menggunakan asumsi bahwa telah dan terus sedang terjadi perubahan iklim di wilayah kabupaten Bandung yang merupakan pemicu (stimuli) kejadian bencana (hazard).

Analisis Bahaya. Analisis bahaya di kabupaten Bandung menggunakan indikator adalah yaitu: (1) Peningkatan suhu udara ratarata; (2) Perubahan pola hujan, baik curah hujan maupun periode kejadiannya; dan (3) Kejadian cuaca ekstrim berupa El-Nino dan La-Nina
Stimuli klimatis tersebut akan berdampak terhadap proses fisiologis tanaman pangan yang pada akhirnya berdampak pula terhadap produksi tanaman pangan baik langsung maupun tidak langsung (Gambar 3).

Analisis Kerentanan. Kerentanan perubahan iklim pada sektor pertanian dapat dikaji dari tiga komponen kerentanan yaitu eksposur (E), sensitivitas (S), dan kapasitas adaptasi (AC). Besarnya kerentanan perubahan iklim di kabupaten Bandung sangat tergantung pada besarnya bobot dari ketiga komponen tersebut. Tingkat kerentanan (V) berbanding lurus dengan eksposur dan sensitivitas serta terbalik dengan kapasitas adaptasi, yang dapat dinyatakan dalam bentuk formulasi berikut ini (Ruminta dan Handoko, 2012a).

$$
\mathrm{V}=\frac{(\mathrm{E} \times \mathrm{S})}{\mathrm{AC}}
$$

$$
\begin{array}{ll}
\mathrm{V} & =\text { Kerentanan } \\
\mathrm{E} & =\text { Eksposur } \\
\mathrm{S} & =\text { Sensitivitas } \\
\mathrm{AC} & =\text { Kapasitas Adaptasi }
\end{array}
$$

Besarnya bobot eksposur, sensitivitas, dan kapasitas adaptasi perubahan iklim di kabupaten Bandung dapat dikaji dari setiap indikatorindikatornya. Indikator eksposur (E) adalah komponen sektor pertanian yang terkena dampak perubahan iklim seperti luas lahan dan jumlah petani. Indikator sensitivitas (S) menggambarkan respon sektor pertanian terhadap perubahan iklim tersebut seperti luas lahan non irigasi, ketinggian tempat, dan pendapatan petani. Sementara itu indikator kapasitas adaptasi (AC) menggambarkan kemampuan sektor pertanian untuk melakukan adaptasi terhadap perubahan iklim, seperti ketersediaan infrastruktur jaringan irigasi, tingkat pendidikan petani, dan akses petani terhadap modal.

Analisis Risiko. Risiko perubahan iklim adalah potensi kerugian yang ditimbulkan akibat perubahan iklim pada suatu wilayah dalam kurun waktu tertentu yang dapat berupa kematian, luka, sakit, jiwa terancam, hilangnya rasa aman, pengungsian, kerusakan, atau kehilangan harta dan gangguan kegiatan masyarakat. Pada sektor pertanian konsep risiko dapat diartikan sebagai suatu kemungkinan yang dapat menyebabkan kerugian yang diwakili oleh penurunan produksi tanaman pangan sebagai bahaya (hazard). Selanjutnya, bahaya penurunan produksi ini dapat mengakibatkan secara langsung maupun tidak langsung terhadap penurunan kesejahteraan petani serta 
penurunan pasokan pangan yang merupakan bagian dari ketahanan pangan di kabupaten Bandung. Diagram alur kajian risiko perubahan iklim pada sektor perantian disajikan pada Gambar 2. Perhitungan resiko (risk) dari perubahan iklim di kabupaten Bandung dihitung menggunakan persamaan sebagai berikut (Ruminta dan Handoko, 2012b):

$$
\mathrm{R}=\mathrm{H} . \mathrm{V}
$$

$\mathrm{R}=\operatorname{Risk}$ (Risiko),

$\mathrm{H}=$ Hazard (Bahaya) yang dihitung pada penurunan produksi pertanian ,

$\mathrm{V}=$ Vulnerability (Kerentanan) yang dihitung pada persamaan 1 .

Formulasi Adaptasi. Adaptasi merupakan tindakan nyata penyesuaian sistem lingkungan fisik dan sosial dengan beberapa prinsip pendekatan untuk menghadapi kemungkinan timbulnya dampak negatif dari perubahan iklim. Perubahan iklim yang diindikasikan antara lain oleh pergeseran musim tanam dan musim panen padi harus diantisipasi untuk meminimalkan dampak berupa bahaya (hazard) dan risiko yang merugikan bagi daerah-daerah yang rentan. Upaya-upaya adaptasi dilakukan untuk mempersiapkan dan mengantisipasi dampak yang mungkin terjadi. Upaya adaptasi berbagai dampak perubahan iklim memerlukan strategi yang berbeda, seperti adaptasi terhadap bencana kekeringan, pergeseran musim hujan, perubahan frekuensi dan kuantitas curah hujan serta kejadian ekstrim lainnya.

\section{Hasil dan Pembahasan}

Bahaya Penurunan Produksi Padi Sawah. Potensi bahaya penurunan produksi tanaman diperoleh dari kajian empirik dengan asumsi bahwa penurunan produksi tanaman pangan mempunyai hubungan yang kuat dengan perubahan suhu udara dan curah hujan. Dampak perubahan iklim terhadap produksi padi dari sawah beririgasi disebabkan oleh kenaikan suhu dan curah hujan dihitung berdasarkan penurunan hasil dan luas panen setelah terjadi perubahan iklim. Luas panen dihitung dari luas lahan sawah irigasi yang dipengaruhi suhu yang menyebabkan peningkatan kebutuhan air tanaman dan tidak dipengaruhi oleh curah hujan secara langsung. Penurunan produksi padi sawah irigasi akibat peningkatan suhu dan perubahan curah hujan dihitung sebagai berikut. Perhitungan penurunan produksi padi sawah tadah hujan seperti pada padi sawah irigasi, kecuali luas panen dipengaruhi oleh curah hujan dan tidak ada pengaruh irigasi. Hasil analisis bahaya penurunan produksi tanaman pangan utama yaitu padi di kabupaten Bandung ditunjukkan pada Gambar 4.

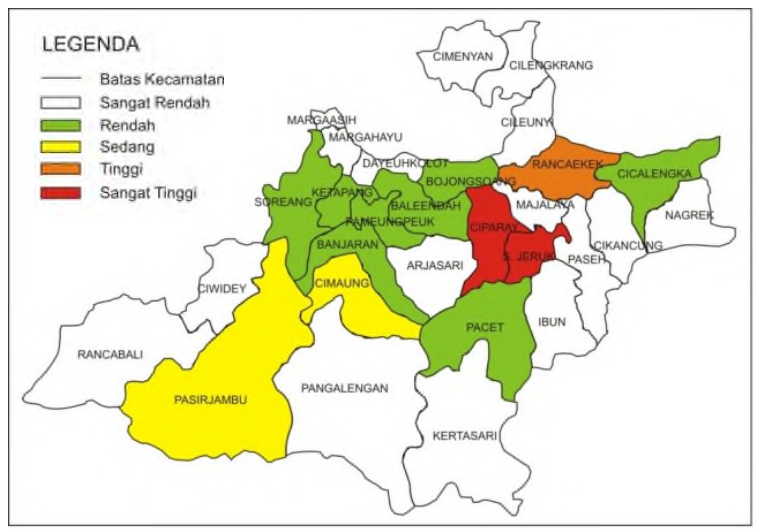

Gambar 4. Peta Spasial Bahaya Penurunan

Produksi Tanaman Padi Sawah di Kabupaten Bandung pada tahun 2030.

Potensi bahaya penurunan produksi padi sawah di wilayah kabupaten Bandung rara-rata sebesar 6706 ton pada tahun 2030. Pada proyeksi skenario penurunan produksi, sebagian besar wilayah kabupaten Bandung mempunyai potensi bahaya penurunan produksi padi sawah tingkat sangat rendah sampai sangat tinggi. Beberapa kecamatan dengan bahaya penurunan produksi tingkat sangat rendah adalah Ciwidey, Rancabali, Pangalengan, Kertasari, Ibun, Paseh, Cikancung, Nagreg, Majalaya, Arjasari, Margaasih, Margahayu, Dayeuhkolot, Cileunyi, Cilengkrang, dan Cimenyan. Kecamatan dengan bahaya penurunan produksi tingkat rendah adalah Pacet, Cicalengka, Baleendah, Banjaran, Cangkuang, Pameungpeuk, Katapang, Soreang, dan Bojongsoang. Bahaya penurunan produksi tingkat sedang dapat terjadi di kecamatan Pasirjambu, Cimaung, dan Kutawaringin. Bahaya penurunan produksi tingkat tinggi dan sangat tinggi dapat terjadi di Rancaekek, Solokanjeruk, dan Ciparay.

Bahaya (hazard) tersebut benar-benar terjadi maka akan muncul risiko (risks) berupa penurunan pasokan bahan makanan padi yang akan mengancam terganggunya ketahanan pangan dan neraca pangan, sehingga kabupaten Bandung tidak dapat berkontribusi terhadap penyediaan stok beras nasional. Berdasarkan prediksi ini, untuk menekan bahaya penurunan produksi tanaman pangan utama di kabupaten Bandung pada daerah-daerah yang rentan 
terhadap perubahan iklim maka perlu dilakukan antisipasi melalui pelaksanaan strategi adaptasi dengan penuh perhitungan dan pertimbangan agar tidak terjadi mal adaptation.

Potensi Kerentanan pada Sektor Pertanian. Kajian kerentanan (V) perubahan iklim pada sektor pertanian di kabupaten Bandung adalah gabungan dari tiga komponen kerentanan yaitu eksposur (E), sensitivitas (S), dan kapasitas adaptif (AC). Kerentanan merupakan rasio antara eksposur dikalikan sensitivitas terhadap kapasitas adaptif. Hasil analisis kerentanan dapat ditunjukkan pada Gambar 5.

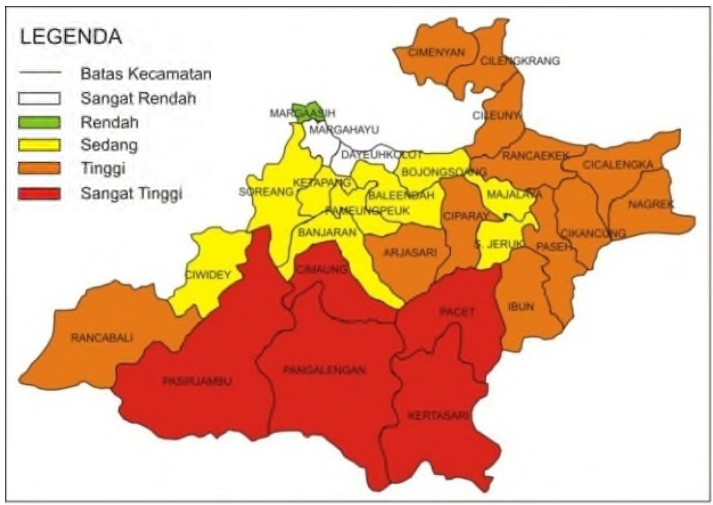

Gambar 5. Peta spasial indeks kerentanan (V) perubahan iklim terhadap sektor pertanian di Kabupaten Bandung

Hasil analisis kerentanan seperti pada Gambar 6 menunjukkan bahwa tingkat kerentanan perubahan iklim pada sektor pertanian di kabupaten Bandung didominasi oleh tingkat kerentanan tinggi seperti di kecamatan Rancabali, Ibun, Paseh, Cikancung, Cicalengka, Nagreg, Rancaekek, Ciparay, Arjasari, Kutawaringin, Cileunyi, Cilengkrang, dan Cimenyan. Tingkat kerentanan sangat tinggi terdapat di Pasirjambu, Cimaung, Pangalengan, Kertasari, dan Pacet. Sementara itu, kecamatan Margahayu dan Dayeuhkolot mempunyai tingkat kerentanan sangat rendah. Kecamatan Margaasih mempunyai tingkat kerentanan rendah. Tingkat kerentanan sedang terdapat di kecamatan Ciwidey, Majalaya, Solokanjeruk, Baleendah, Banjaran, Cangkuang, Pameungpeuk, Katapang, Soreang, dan Bojongsoang. Kecamatan yang mempunyai tingkat kerentanan yang sangat tinggi karena di kedua wilayah tersebut mempunyai tingkat eksposur dan sensitivitas sangat tinggi sementara itu tingkat kapasitas adaptifnya sangat rendah. Perlu upayaupaya adaptasi strategis agar kerentanan tersebut tidak mengganggu produksi pertanian dan ketersediaan pangan serta swasembada pangan di wilayah kabupaten Bandung.
Risiko Penurunan Produksi Padi Sawah. Hasil analisis risiko menggambarkan bahwa berdasarkan faktor-faktor tersebut secara spasial menunjukkan tingkat bahaya dan kerentanan yang berbeda antar kecamatan di wilayah kabupaten Bandung. Hal ini dapat difahami karena risiko merupakan perkalian antara kerentanan (vulnerability) dan bahaya (hazard). Hasil analisis risiko penurunan produksi tanaman pangan utama yaitu padi di kabupaten Bandung pada tahun 2030 dapat diperoleh dari hasil skenario yang ditunjukkan pada Gambar 6.

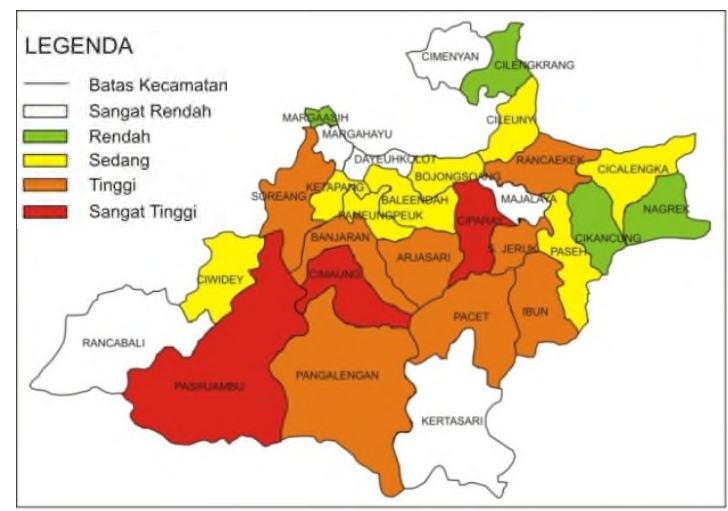

Gambar 6. Peta Spasial Risiko Penurunan Produksi Tanaman Padi Sawah di Kabupaten Bandung pada Tahun 2030.

Berdasarkan hasil analisis proyeksi risiko penurunan produksi tanaman padi di Kabupaten Bandung pada tahun 2030 dapat disimpulkan bahwa:

1) Ada tiga kecamatan yang mempunyai risiko penurunan produksi padi sawah yaitu Kecamatan Pasirjambu, Cimaung, dan Ciparay.

2) Ada lima kecamatan di kabupaten Bandung yang mempunyai risiko penurunan produksi padi ladang yaitu kecamatan Ciwidey, Pasirjambu, Cimaung, Pacet, dan Arjasari.

Hasil analisis menunjukkan bahwa Kecamatan Pasirjambu, Cimaung, dan Ciwidey mempunyai risiko penurunan produksi tanaman padi yang cukup serius pada tahun 2030. Di ketiga kecamatan tersebut perlu upaya adaptasi strategis terhadap perubahan iklim agar tingkat produksi tanaman tersebut dapat dipertahankan paling tidak seperti pada kondisi sekarang. Adanya potensi penurunan produksi tanaman padi di wilayah tersebut akan akan mengganggu pasokan dan capaian swasembada pangan di wilayah kabupaten Bandung.

Strategi Adaptasi Terhadap Penurunan Produksi Padi Sawah. Hasil analisis risiko penurunan produksi tanaman Padi akibat 
perubahan iklim menunjukkan bahwa terdapat empat kecamatan yang berisiko tinggi dan sangat tinggi yaitu kecamatan Pasirjambu, Cimaung, dan Ciparay untuk tanaman padi sawah; dan kecamatan Ciwidey, Pasirjambu, Cimaung, Pacet, dan Arjasari untuk tanaman padi ladang. Wilayah-wilayah tersebut umumnya didominasi oleh lahan tadah hujan dan lahan kering dan juga mengalami peningkatan suhu udara dan penurunan curah hujan. Di sisi lain wilayah tersebut tidak mempunyai jaringan irigasi yang memadai sehingga potensi kekeringan sangat tinggi sehingga produksi tanaman mengalami penurunan.

Tabel 2. Ringkasan strategi adaptasi terhadap dampak perubahan iklim pada lahan sawah di Kabupaten Bandung.

\begin{tabular}{|c|c|c|c|c|}
\hline $\begin{array}{c}\text { Bahaya } \\
\text { Penurunan } \\
\text { Produksi } \\
\text { Padi } \\
\text { (H) }\end{array}$ & $\begin{array}{c}\text { Keren- } \\
\text { tanan } \\
(\mathrm{V})\end{array}$ & $\begin{array}{c}\text { Risiko } \\
\text { Penurunan } \\
\text { Produksi } \\
\text { Padi } \\
\text { (R) } \\
\end{array}$ & & Strategi Adaptasi \\
\hline Berbahaya & Rentan & Berisiko & $\begin{array}{l}1 . \\
2 . \\
3 . \\
3 . \\
5 . \\
\end{array}$ & $\begin{array}{l}\text { Penggunaan varitas } \\
\text { padi unggul (produksi } \\
\text { tinggi dan tahan } \\
\text { kekeringan/ banjir) } \\
\text { bermutu yang } \\
\text { berumur genjah. } \\
\text { Meningkatkan teknik } \\
\text { budidaya pertanian } \\
\text { misalnya melalui } \\
\text { pengelolaan tanaman } \\
\text { terpadu (PTT) dan } \\
\text { intensifikasi budidaya } \\
\text { misalnya SRI dan } \\
\text { sistem Legowo } \\
\text { Pengembangan } \\
\text { usahatani sistem } \\
\text { bedeng untuk tujuan } \\
\text { konservasi tanah dan } \\
\text { air di lahan tadah } \\
\text { hujan. } \\
\text { Optimalisasi } \\
\text { pemanfaatan lahan } \\
\text { tadah hujan dengan } \\
\text { pompanisasi air irigasi } \\
\text { dan penghijauan. } \\
\text { Optimalisasi } \\
\text { pemanfaatan lahan } \\
\text { tidur dan pembukaan } \\
\text { lahan baru }\end{array}$ \\
\hline
\end{tabular}

Wilayah-wilayah yang berisiko tinggi dari penurunan produksi disebabkan oleh bahaya (hazard) yang tinggi akibat adanya peningkatan suhu udara dan penurunan curah hujan dan faktor-faktor kerentanan yang tinggi terhadap perubahan iklim dimana tingkat eksposur dan sensitivitas yang tinggi sedangkan tingkat kapasitas adaptifnya rendah. Risiko penurunan produksi disebabkan oleh tiga alternatif bahaya, yakni bahaya peningkatan suhu udara, curah hujan yang sangat kurang pada masa tanam, atau curah hujan yang sangat besar disertai banjir pada masa tanam dapat menyebabkan berkurangnya produksi pertanian. Alternatif strategi adaptasi untuk daerah yang memiliki risiko penurunan luas lahan tanaman pangan utama. Strategi adaptasi ini merupakan integrasi dari seluruh strategi adaptasi terhadap risiko penurunan produktivitas tanaman, luas panen, dan luas lahan disajikam pada Tabel 2.

\section{Kesimpulan dan Saran}

Berdasarkan hasil analisis bahaya, kerentanan, dan risiko perubahan iklim pada sektor pertanian di kabupaten Bandung maka dapat dikemukakan kesimpulan berikut ini.

a. Dampak perubahan iklim di kabupaten Bandung sudah dirasakan oleh masyarakat yang diindikasikan oleh bergesernya musim tanam dan panen, luas panen. luas lahan, penurunan produktivitas, dan produksi tanaman padi di beberapa lahan sawah tadah hujan dan lahan sawah $1 / 2$ irigasi.

b. Hasil analisis bahaya (hazard) perubahan iklim pada sistem pertanian tanaman padi menunjukkan daerah-daerah yang bahaya terhadap penurunan produksi tanaman padi adalah kecamatan Cicalengka, Pangalengan, Ciwidey, Solokanjeruk, dan Ciparay.

c. Hasil analisis kerentanan (vulnerability) terhadap perubahan iklim di kabupaten Bandung maka daerah-daerah yang sangat rentan adalah kecamatan Pasirjambu, Cimaung, Pangalengan, Kertasari, dan Pacet (tingkat kerentanan sangat tinggi).

d. Wilayah-wilayah yang mempunyai risiko penurunan produksi tanaman padi adalah kecamatan Pasirjambu, Cimaung, dan Ciparay (padi sawah); dan kecamatan Ciwidey, Pasirjambu, Cimaung, Pacet, dan Arjasari (padi ladang).

e. Ada beberapa pilihan adaptasi strategis untuk menghadapi risiko penurunan produksi tanaman padi akibat perubahan iklim agar tidak terjadi mal-adaptasi.

Adapun rekomendasi agar penurunan produksi tanaman padi akibat perubahan iklim dapat dikurangi ada beberapa pilihan adaptasi strategis yaitu : 
a. Penggunaan varitas padi unggul (produksi tinggi dan tahan kekeringan/ banjir) bermutu yang berumur genjah.

b. Meningkatkan teknik budidaya pertanian misalnya melalui pengelolaan tanaman terpadu (PTT) dan intensifikasi budidaya misalnya SRI dan sistem Legowo

c. Pengembangan usahatani sistem bedeng untuk tujuan konservasi tanah dan air di lahan tadah hujan.

d. Optimalisasi pemanfaatan lahan tadah hujan dengan pompanisasi air irigasi dan penghijauan.

e. Optimalisasi pemanfaatan lahan tidur dan pembukaan lahan baru

\section{Daftar Pustaka}

Abawi, Y. I Yasin, S. Dutta, T. Harris, M. Ma'shum, D. McClymont, I. Amien dan R. Sayuti. 2002. Capturing the benefit of seasonal climate forecast in agricultural management: Subproject 2- Water and Crop Management inIndonesia. Final Report to ACIAR. QCCADNRM. Toowoomba Australia.

Boer, R and Meinke, H. 2002. Plant Growth and the SOI, in Will It Rain? The effect of the Southern Oscillatioon and El Nino in Indonesia. Department of Primary Industries Queensland, Brisbane Australia.

BPS. 2009. Kabupaten Bandung Dalam Angka Tahun 2009. Badan Pusat Statistik Kabupaten Bandung

BPS. 2013. Kabupaten Bandung Dalam Angka Tahun 2013. Badan Pusat Statistik Kabupaten Bandung.
Dinas Pertanian Kabupaten Bandung. 2008. Laporan Tahunan 2007.

Dinas Pertanian Kabupaten Bandung. 2009. Laporan Tahunan 2008. Pemerintah Kabupaten Bandung.

IPCC, 2007. Climate Change 2007-Impacts, Adaptation and Vulnerability. Contribution of Working Group II to the Fourth Assessment Report of the IPCC. Cambridge University Press. New York.

Martyn. D. 1992. Climate of the world. Development in Atmospheric Science. Elsevier Amsterdam London, N.Y. 435p.

Oldeman, L.R. 1975. An Agroclimatic Maf of Java. CRIA (LP3). Bogor.

Ruminta dan Handoko. 2012a. Kajian Risiko dan Adaptasi Perubahan Iklim Pada Sektor Peranian di Sumatera Selatan. Laporan Penelitian. KLH Jakarta.

Ruminta dan Handoko. 2012b. Kajian Risiko dan Adaptasi Perubahan Iklim Pada Sektor Peranian di Malang Raya. Laporan Penelitian. KLH Jakarta.

Yasin, I., M. Ma'shum, Y. Abawi, dan L. Hadiawati. 2002. Penggunaan Flowcast untuk Menentukan Awal Musim Hujan dan Menyusun Strategi Tanam di Lahan Sawah Tadah Hujan di Pulau Lombok. Pros. Seminar Nasional Peningkatan Pendapatan Petani Melalui Penerapan Teknologi Tepat Guna. BPTP NTB.

Yasin, I., M. Ma'shum, Y. Abawi, and Lia Hadiawaty. 2002. Flowcast Use To Determine Early Summer Rain and Develop Strategy of Land Rice Cultivation in Rainwater in Lombok Island. Nat. Sem. Proc. "Farmer Income Improvement Through Agricultural Resources Utilization and Application of Appropriate Technology" on 20-21 Nov. 2002. BPTP NTB 